\title{
What Kind of Training is Required to Help Language Students Use Metaphor-Based Strategies to Work Out the Meaning of New Vocabulary?
}

(Que Tipo de Treinamento é Necessário para Ajudar Estudantes de Idiomas a Usar Estratégias Baseadas em Metáforas para Adivinhar o Significado de Vocabulário Novo?)

\author{
Jeannette LITTLEMORE \\ (University of Birmingham)
}

\begin{abstract}
A study is described, which compared the benefits of two different training approaches in the use of metaphor-based vocabulary guessing strategies for foreign language learners. A group-based, step-by-step approach was compared with a more autonomous approach. The findings suggest that the type of training received affects the students' ability to use these strategies, but not their tendency to use them. The students who participated in the autonomous approach were significantly more successful at using metaphor-based vocabulary guessing strategies than the students who had received the group training. The difference was particularly marked in terms of their successful use of interactive images.
\end{abstract}

KEY-WORDs: Language Learning; Metaphor; Individual Differences; Imagery.

RESUMo: É descrito um estudo que compara os benefícios de duas abordagens diferentes de treinamento no uso de estratégias de adivinhação de vocabulário baseadas em metáforas para estudantes de línguas estrangeiras. Uma abordagem passo-a-passo, de grupo, é comparada com outra, mais autônoma. Os resultados sugerem que o tipo de treinamento recebido afeta a capacidade dos alunos usarem essas estratégias, mas não sua tendência em usá-las. Alunos que participaram da abordagem autônoma foram significativamente melhor sucedidos no uso de estratégias de adivinhação de vocabulário baseadas em metáforas do que os alunos que receberam treinamento em grupo. A diferença foi particularmente acentuada em relação a seu sucesso no uso de imagens interativas.

PaLAVRas-CHAVE: Aprendizado de Línguas; Metáfora; Diferenças Individuais; Linguagem Figurada. 


\section{Introduction}

Recent developments in the field of cognitive linguistics have suggested that conceptual metaphors motivate a great deal of our abstract thinking (Lakoff and Johnson, 1980), and that there is a great deal of systematicity underlying aspects of language that have previously been considered arbitrary (Lindstromberg, 1991). Not surprisingly, language teachers and researchers have been exploiting these findings in order to help students learn and remember grammar and vocabulary in the target language. Researchers such as Boers (2000) and Charteris-Black (2002) have shown that if language learners are sensitized to the conceptual metaphors underlying aspects of the language that they are learning, then they tend to be better at understanding and retaining them.

Another way in which metaphor can be exploited to promote language learning is by focusing on word-formation processes. When languages develop, the word-formation processes are often metaphorical or metonymical (see, for example, Dirven, 1985). For example, in English, the meaning of the word 'eye' has been extended both metaphorically and metonymically to refer not only to a part of the body, but also to the centre of a dartboard, a black spot in a potato and a hole in a needle. Although for native speakers these uses are highly conventional, for language learners they are likely to be novel.

In an earlier study (Littlemore, 2002), I discussed the benefits of helping learners to work out the meaning of such expressions by employing metaphor-based vocabulary guessing strategies. In this article, I will assess whether this type of training is best carried out through a group-based approach, or through a more individualised approach. In section 2, a brief description is provided of metaphor-based vocabulary guessing strategies, along with an outline of the psychological processes thought to underlie them. In section 3, I discuss the relative benefits of adopting a groupbased or an individualised approach, and explain why it is important to decide which of these two approaches is more effective.

\section{Metaphor-based vocabulary guessing strategies}

Metaphor-based vocabulary guessing strategies are best illustrated with an example: Let us consider the term 'targeting' in the following context 
'Identifying and targeting the right customers are both vital to a firm's success'. It is likely that many students will be familiar with the literal meaning of the noun 'target', but they may not have come across this metaphorical extension of the word, in the business context. In order to work out its meaning, a student might begin by recalling the literal meaning of the word 'target'. The teacher could help by sketching an archery target, along with a bow and arrow ${ }^{1}$. The student could then be encouraged to think of as many associated concepts as possible. They might come up with the concepts of focusing on the target, taking aim and firing something at it. The student could then be asked to relate these concepts to the surrounding context. He or she might think of a typical customer base being studied in detail, of products being designed to meet the needs of this customer base, and of products being advertised in the types of magazines that are usually read by these customers. The student could then be asked to form an interactive image of the metaphor (for example, a firm firing a product at a particular customer, who is standing in a group). This may lead to further interpretations including, the fact that it is important to identify the right customer, to see what that customer looks like, to find an appropriate arrow to hit that particular customer, and that there are difficulties inherent in the whole process. A student using this technique is more likely to appreciate the depth and breadth of meaning of a word than a student who simply has it explained to them by the teacher.

Metaphor-based vocabulary guessing strategies are likely to involve the psychological processes of associative fluency, analogical reasoning and image formation. Each of these processes is described in detail below.

Associative fluency refers to the ability to make a wide range of connections when presented with a given stimulus (see Guilford, 1967; Carroll, 1993). It is likely to be involved in the first stages of novel metaphor interpretation, as subjects need to search the networks of associations surrounding the source domain in order to find areas that might overlap with the target domain. Individuals who are skilled in associative fluency are likely to come up with more possible meanings than those who are less skilled (see Pollio \& Smith, 1980 and Littlemore, 2001).

\footnotetext{
1 Variations may be necessary here, according to the cultural background of the student and the teacher.
} 
Analogical reasoning involves the observation of partial similarities between concepts so that the characteristics of one of the concepts can be used to shed light on the other (Holyoak, 1984). The role of analogy in the process of novel metaphor interpretation has been outlined by Paivio and Walsh (1993), who claim that the capacity to perceive partial similarity between apparently disparate domains is central to all kinds of metaphoric processing. When language learners are faced with unfamiliar, metaphorically-derived words, only the source domains are given, the target domains usually have to be inferred from the context. The student must first infer the target domain from the surrounding context. Then he or she can engage in analogical reasoning and identify similarities between source and target domains. The analogical reasoning must therefore take place between the unknown word and the context in which it appears. In other words, effective metaphor interpretation in context requires that the student is able to access as many meanings as possible for the base concept (associative fluency), whilst identifying all possible links between this concept and the surrounding context (analogical reasoning).

The use of mental imagery is likely to help individuals to engage in both associative fluency and analogical reasoning. It has been argued that image generation serves as a powerful tool in metaphor comprehension, as it allows different pieces of information that are represented visually to be recalled simultaneously, whereas different pieces of information which are represented verbally can only be recalled sequentially (Paivio and Walsh, 1993). The imageability of metaphors has also been found to be related to the ease with which they can be understood (Katz et al., 1988; Harris et al., 1980), thus implying that imagery might help the associative and analogical processes involved in metaphor comprehension. In order to help students to understand the metaphorical meaning of new expressions, it may therefore be beneficial to encourage them to form a mental image of those expressions.

In this section, we have seen what metaphor-based vocabulary guessing strategies are, and looked at some of the psychological processes that may be involved when they are employed. The following section will discuss how language learners might best be trained to use these strategies. In particular, it will assess the relative advantages of adopting a group-based or an individualised approach to the training. 


\section{What is best, a group-based approach or an individualised approach?}

When training students to employ metaphor-based vocabulary guessing strategies, teachers can adopt a step-by-step group-based approach, or they can give students opportunities to develop the required skills for themselves. The advantage of taking a group-based approach is that it may help students appreciate the full potential of the strategies, and may help them to access meanings that may, at first sight, be less than obvious to them. In other words, it may help them see the metaphor from another person's point of view. The advantage of a more individualized approach is that it is more likely to accommodate differences in the students' types of knowledge and their preferred interpretation strategies.

As we saw above, metaphor comprehension involves searching the networks of associations surrounding the source domain in order to find areas that might overlap with the target domain. Networks of associations for a given concepts are sometimes referred to as 'frames'. Frames are global patterns of common-sense knowledge about some central concept. The knowledge encapsulated in a frame is knowledge that is shared, by at least some segment of a speech community (Taylor, 1989). For example, for many people, the word 'teacher' might have the following frame:

- A person (probably an adult) who works in a school;

- A person who has specialist knowledge about a subject or a range of subjects;

- A person who conveys this knowledge to the students;

- A person who holds a position of power.

However, due to our own personal experiences, we all have our own idiosyncratic associations that we can add to this list. For example, we might add that a teacher is:

- Often bossy

- Underpaid

Therefore, although the various pieces of information that are associated with any given concept are largely socially constructed, there is also room for a degree of individual variation. This means that within any given group of individuals, the members are likely to have slightly idiosyncratic, 
but largely overlapping frames. Successful metaphor interpretation is likely to require full access to our own frame $e^{2}$, and possibly the ability to 'second guess' the frame of the person who produced the metaphor. For language learners who are being trained to employ metaphor-based vocabulary guessing strategies, an ability to carry out a wide search of their own frame might be promoted through an individualized training approach. On the other hand, a group approach may make them more aware of possible differences between their own frames and those of their peers.

There are therefore advantages to both approaches. An individualized approach is likely to lead to increased learner autonomy in the long run: autonomous students are likely to be better able to work out the meaning of new vocabulary than students who have been encouraged to rely to heavily on the teacher. On the other hand, students who have learned the technique through a group-based approach may be better at secondguessing the frame of the person who produced the metaphor as they are more used to seeing another person's point of view. It is therefore useful to assess the relative effectiveness of group-based approaches versus individualised training approaches.

In the following section, I describe a study that was designed to evaluate the effectiveness of a group-based training approach and an individual training approach. It looked at the relative effects of the two approaches on the students' tendency to use metaphor-based vocabulary guessing strategies, and on their ability to use these strategies.

\section{The study}

The participants in the study were forty-two international students studying for post-graduate qualifications at a British university. The study sought to answer two research questions:

\footnotetext{
2 It is important to note here that, according to the 'direct access view' of metaphor interpretation, listeners and readers do not necessarily need to access the complete literal meaning of figurative expressions in order to interpret their meaning in a given context (Gibbs, 2001: 318). However, it is probably helpful for them to have the 'complete' (or 'wide frame') literal meaning available for access as and when they need it.
} 
1. Does the type of training received affect the students' tendency to use metaphor-based vocabulary guessing strategies?

2. Does the type of training received affect the students' ability to use metaphor-based vocabulary guessing strategies?

\begin{tabular}{|c|c|}
\hline Test sentence & Image \\
\hline $\begin{array}{l}\text { Identifying and targeting the right } \\
\text { students are both vital to the } \\
\text { university's success. }\end{array}$ & An archery target. \\
\hline $\begin{array}{l}\text { Many of the problems that new } \\
\text { students face are rooted in cultural } \\
\text { differences. }\end{array}$ & The roots of a tree. \\
\hline $\begin{array}{l}\text { In this university, old attitudes are } \\
\text { often challenged, and staff are } \\
\text { discouraged from holding myopic } \\
\text { views. }\end{array}$ & $\begin{array}{l}\text { A pair of glasses with the caption } \\
\text { 'if you are myopic, you need these } \\
\text { in order to see far away'. }\end{array}$ \\
\hline $\begin{array}{l}\text { His outlook remains firmly } \\
\text { anchored in the liberal tradition. }\end{array}$ & A ship's anchor. \\
\hline $\begin{array}{l}\text { Although the various pitfalls that } \\
\text { students fall into are related, they } \\
\text { tend to occur at different stages. }\end{array}$ & A cartoon of a man falling into a pit. \\
\hline $\begin{array}{l}\text { Innovative vocabulary teaching } \\
\text { methods, spawned by the internet, } \\
\text { have the potential to make language } \\
\text { teachers lose their jobs. }\end{array}$ & $\begin{array}{l}\text { A frog producing vast quantities } \\
\text { of spawn. }\end{array}$ \\
\hline $\begin{array}{l}\text { By the late 1990s, even big names, } \\
\text { such as IBM and Hewlett Packard } \\
\text { had joined the bandwagon. Intel's } \\
\text { chips were used in computers of more } \\
\text { than } 1,600 \text { manufacturers. }\end{array}$ & $\begin{array}{l}\text { A wagon with a band playing on it, } \\
\text { and a crowd following. }\end{array}$ \\
\hline $\begin{array}{l}\text { The University English Department } \\
\text { has embraced all of these new ideas. }\end{array}$ & Two people embracing. \\
\hline $\begin{array}{l}\text { I've invested all my money in this } \\
\text { company, and we're only just } \\
\text { managing to stay afloat. }\end{array}$ & $\begin{array}{l}\text { People on a raft in a rough sea, } \\
\text { only just managing to stay afloat. }\end{array}$ \\
\hline $\begin{array}{l}\text { I was wasting my time on those art } \\
\text { classes, so I've decided to channel my } \\
\text { energy into something different instead. }\end{array}$ & $\begin{array}{l}\text { A river breaking up into several channels, } \\
\text { with the caption 'this river is breaking } \\
\text { up into several channels'. }\end{array}$ \\
\hline
\end{tabular}

Figure 1: Items used in the training sessions 
In order to answer these research questions, the participants were divided into two groups. Each group received a thirty-minute training session one week before being asked to carry out a test of their ability to employ metaphor-based vocabulary guessing strategies. Each of these training sessions began with students being given a general explanation to the strategies (see Appendix 1).

With the first two groups $\left(\mathrm{N}=27^{3}\right)$, the teacher then went through the items presented in Figure 1 below. She sketched the associated images on the blackboard and asked the students, as a group, to brainstorm the possible meanings. They were encouraged to employ associative fluency, analogical reasoning and image formation. This was designated the 'group training approach'.

With the second group $(\mathrm{N}=15)$, a different approach was employed. After having gone through the procedure outlined in Appendix 1, the teacher distributed individual handouts containing the same ten items that are listed in Table 1. Each item was accompanied by an appropriate image and the participants were asked to work individually to work out the meanings of the underlined words. This approach was designated the 'individualised training approach'.

One week after the training sessions, the participants were invited to attend a testing session in which they were presented with the ten items listed in Figure 2. These ten items all originally appeared in the Financial Times ${ }^{4}$. They were selected from a longer list on the basis of a pilot test. In this pilot test, fifteen students, of an equivalent level to those in the study, were found to be familiar with the literal meanings of the underlined words, but not their metaphorical extensions in these contexts. These students were able, with the help of their teacher, to use these literal meanings to guess the metaphorical meanings of the words in context. The items, in their surrounding contexts, were as follows:

\footnotetext{
This group actually consisted of two separate classes of thirteen and fourteen students respectively.

4 Occasionally, the name of a company was changed to a more general noun, such as 'the university'.
} 
1. Established companies seldom commit wholeheartedly to new innovations.

2. The needs of the students fit squarely with the university's objectives.

3. Changing peoples' views is not always easy because attitudes are often grounded in experience.

4. The new management must be willing to challenge deep-seated assumptions.

5. The task is going to be enormous, however we have managed to make a few inroads already.

6. It is natural to underestimate developing technologies because initially they don't always measure up to the familiar alternatives.

7. Scientists made an important breakthrough when they discovered how to clone sheep.

8. There has been a gradual build-up of troops on both sides of the border.

9. Lecturers tend to focus on the best students, but it's important for them to consider the needs of also-rans.

10. Global companies must also be able to exploit new opportunities and surmount the challenges of globalisation.

Figure 2: Items used in the testing session

The participants were asked to write down the meanings of the underlined words and expressions, and for each item they were asked to indicate which strategies they had used. The answer sheet is reproduced in Figure 3:

Meaning of the underlined expression in this context:

Please indicate with an ' $\mathrm{X}$ ', which strategies you used when trying to work out the meaning:

a. I worked out the meaning of the word using only the surrounding context

b. I formed a mental image of the word and used this mental image to help me think of associated concepts

c. I thought of the word's associated concepts, without using an image

d. I formed an interactive image between the word and its context

e. I knew the word and didn't need to do any of the above

Figure 3: The answer sheet used in the testing session

Each of the items was allocated a score between 0 and 2, where 0 indicated a completely wrong response, 1 indicated a partially correct response and 2 indicated a completely correct response. Two scorers (both 
of whom were native speaker language teachers) worked independently and agreement was reached in $92 \%$ of all cases. In the remaining $8 \%$ of cases, discussion took place until the scorers could agree. Examples are given in Figure 4:

0 = Completely Wrong:

Target item: The new management must be willing to challenge deep-seated assumptions

Participant's response: The new management must be willing to challenge some difficulties that you haven't imagined

$1=$ Partially Correct:

Target item: We have managed to make a few inroads

Participant's response: Parts

2 = Completely Correct:

Target item: It's important for them to consider the needs of the also-rans

Participant's response: they should also consider the other students $w$ bo are not the best students

Figure 4: Examples designed to illustrate the scoring procedure

The scores of those students who had received the group training were compared with the scores of those who had completed the individual exercise. Comparisons were then made between these groups for tendency to use metaphor-based vocabulary guessing strategies and ability to use these strategies. The statistical significance of any differences between the groups was calculated by means of independent samples T-tests.

\section{Results}

It will be remembered that the study aimed at answering two research questions:

1. Does the type of training received affect the students' tendency to use metaphor-based vocabulary guessing strategies?

2. Does the type of training received affect the students' ability to use metaphor-based vocabulary guessing strategies? 
In order to answer the first research question, the responses of the participants who had received the group training $(\mathrm{N}=27)$ were compared with the responses of the participants who had completed the individual exercise $(\mathrm{N}=15)$. Particular attention was paid to the number of times they selected responses b, c and d in Figure 3. No significant differences were found in the number of times they selected any of these strategies. These findings suggest that the type of training received does not affect the students' tendency to use metaphor-based vocabulary guessing strategies.

In order to answer the second research question, the overall scores for both groups were compared. The participants who had completed the individual exercise significantly outperformed those who had received the group training $(t=-4.227$, d.f. $=40, \mathrm{p}<0.05)$. A more detailed analysis of the strategies used revealed a significant difference with respect to their ability to use interactive images to help them work out the meaning of new $\operatorname{vocabulary}^{5}(\mathrm{t}=-1.603$, d.f. $=40, \mathrm{p}<0.1)$. There were no significant differences for the other strategies. Thus the participants who had completed the individual exercise were significantly more successful at using metaphorbased vocabulary guessing strategies than the participants who had received the group training, and the difference was particularly marked for the successful use of interactive images. These findings suggest that the type of training received does affect the students' ability to use metaphor-based vocabulary guessing strategies, particularly with regard to interactive images.

\section{Discussion}

The findings revealed in this study suggest that when training students to use metaphor-based vocabulary guessing strategies, it is useful to give them opportunities to develop the strategy on an individual basis. The use of metaphor-based vocabulary guessing strategies is likely to be a very personal activity, owing to variation in the frame that individuals have for any given source domain. In other words, a given item is likely to activate a different set of associations for each learner, and the learners need to develop the ability to search their own frames, not those of the teacher.

\footnotetext{
5 A student's ability to use the different strategies was calculated by weighting their strategy choices for each item, according to the score they had received for that item.
} 
Individuals are also likely to favour different strategies for searching their frames and applying what they find to the surrounding context. For example, Miller (1987) writes that 'convergent' and 'divergent' thinkers adopt different retrieval strategies. He claims that when 'convergent' thinkers retrieve information from memory, their search is narrowed down to one item. 'Divergent' thinkers on the other hand search for an unspecified number of items - there is no simple or correct end-point to the search. $\mathrm{He}$ describes convergent retrieval strategies as being 'narrow, deductive, logical and using sharper search criteria' (op.cit.: 260), whilst divergent strategies are 'broad, associational rather than logical and use vague search criteria' (ibid.:260). This may have significant implications for the metaphor interpretation strategies of foreign language learners. Convergent processors might spend time looking for a single, 'exact' meaning, whereas divergent processors might be happy with a cluster of meanings.

These sources of variation may go some way towards explaining why the students who had received the individualised training performed better than those who had received the group-based training. We might therefore conclude that, when language learners are being trained to use metaphorbased vocabulary guessing strategies, they should first be introduced to the general approach, and then given opportunities to explore how the strategy might work best for them, taking account of their own background knowledge and cognitive styles.

The main implication of these findings is that metaphoric processing is a highly personalised phenomenon. This means that it is best for language teachers not to interfere too much, but to let their learners use their own associative networks, develop their own analogical reasoning abilities, and form their own images where appropriate. Further research is need in order to better understand the nature of these psychological processes, and to assess the extent individual differences in metaphor interpretation techniques. Such research might take the form of associative group analysis (Szalay, 1984), where people are encouraged to list the main associations which come to mind when presented with a given stimulus, or goal-directed thinkaloud techniques (Cameron, 2003), where subjects are encouraged to reflect on the metaphor-interpretation task at hand whilst in the process of carrying out that task. Another approach might be to make video recordings of students whilst they are interpreting metaphors in the target language, and to pay attention to clues in their body language that may 
indicate the presence of certain lines of reasoning (Littlemore, in press). Such techniques could give us valuable insights into the extent to which, and manner in which people's responses vary, when asked to interpret the same metaphor.

E-mail: j.m.littlemore@bham.ac.uk Recebido em novembro de 2002 Aprovado em outubro de 2003

\section{REFERENCES}

BOERs, F. 2000. Enhancing metaphoric awareness in specialised reading. English for Specific Purposes 19: 137-147.

Cameron, L. 2003. Metaphor in Educational Discourse. London: Continuum.

Carroll, J.B. 1993. Human Cognitive Abilities. A Survey of Factor-Analytic Studies. Cambridge. Cambridge University Press.

Charteris-Black, J. 2002. Second language figurative proficiency: A comparative study of Malay and English. Applied Linguistics 23 (1): 104-133.

Dirven, R. 1985. Metaphor as a basic means for extending the lexicon. In P. Paprotte and R. Dirven (Eds.) The Ubiquity of Metaphor. Amsterdam. John Benjamins Publishing Company: 85-119.

GiBBs, R. 2001. Evaluating contemporary models of figurative language understanding. Metaphor and Symbol 16 (3\&4): 317-333.

Guilford, J.P. 1967. The Nature of Human Intelligence. New York: McGraw Hill.

Harris, R.J., M.A Lahey, \& F. Marsalek 1980. Metaphors and images: Rating, reporting and remembering. In R.P. Honeck and R.R. Hoffman (Eds.) Cognition and Figurative Language. Hillsdale NJ: Erlbaum: 163-181.

HolYOAK, K. 1984. Analogical thinking and human intelligence. In R. Sternberg (Ed.) Advances in the Psychology of Human Intelligence 199230. Hillsdale NJ: Lawrence Lawrence Erlbaum.

Katz, A.N., A Paivio, M.Marschark, \& J.M. Clark 1988. Norms for 204 literary and 260 nonliterary metaphors on 10 psychological dimensions. Metaphor and Symbolic Activity 3 (4): 191-214.

Lakoff, G. \& M. Johnson 1980. Metaphors We Live By. Chicago: University of Chicago Press. 
Lindstromberg, S. 1991. Prepositions: meaning and method, ELT Journal 50 (3): $225-236$.

LitTlemore, J. 2001. Metaphoric competence: A language learning strength of students with a holistic cognitive style? TESOL Quarterly 35 (3): 459-491.

2002. Developing metaphor interpretation strategies for students of economics: a case study. Les Cabiers de l'APLIUT 22 (4): 40-60. in press. Interpreting metaphors in the ELT classroom. To appear in Les Cabiers de l'APLIUT.

Miller A. 1987. Cognitive Styles: An Integrated Model. Educational Psychology 7 (4): 251-268.

Paivio, A. \& M. Walsh 1993. Psychological processes in metaphor comprehension and memory. In A. Ortony (Ed.) Metaphor and Thought 307-328. Cambridge: Cambridge University Press.

Pollio, H.R. \& M. Smith 1980. Metaphoric competence and complex human problem solving. In Honeck and R.P. Hoffman (Eds.) Cognition and Figurative Language 365-392, New Jersey: Erlbaum Press.

Riding, R. J. \& Cheema, I. 1991. Cognitive styles - An overview and integration. Educational Psychology 11 (3+4): 193-215.

SzAlay, L.B. 1984. An in-depth analysis of cultural/ideological belief systems. Mankind Quarterly 25: 71-100.

TAYLOR, J.R. 1989. Linguistic Categorization. Prototypes in Linguisic Theory. Oxford: Clarenson Paerbacks. 


\section{Appendix 1 \\ Instructions in how to use the metaphor interpretation strategy}

If you think hard, you may find that you know the literal meaning of the word, or a rough equivalent in your own language, but cannot think of what it means in this particular context...

Try the following...

Imagine you come across the following expression:

It was time for her to finish with her boyfriend. Their relationship had become a bit entrenched and it was time for her to move on ....

You do not know the meaning of the word 'entrenched' but have some idea of meaning of 'trench'.

1. Form a mental image of a 'trench'

2. Think of concepts associated with this image (people have been there a long time, there is no clear escape, people are bored and tired, everyone is stuck in the mud...)

3. Apply concepts associated with the word 'trench' to the context of 'relationships'

4. Form an interactive image between 'trench' and 'relationships'

What do you think an 'entrenched relationship' is?

\section{Summary of this procedure:}

Can you form a mental image of the word?

What words/ideas do you associate with this image?

Can you apply any of these words/ideas to the context of the article?

Can you an interactive image combining the new word and the context in which it appears?

You might, of course, carry out the whole procedure without forming a mental image... 


\title{
Estudios de Sociolingüística \\ Linguas, sociedades e culturas
}

\author{
Volumes 3(2) $2002 \&$ 4(1) 2003
}

\section{EDITORES / EDITORS}

\author{
Xoản Paulo Rodríguez-Yáñez \\ Anxo M. Lorenzo Suárez \\ Fernando Ramallo \\ Universidade de Vigo \\ Universidade de Vigo \\ alorenzo@uvigo.es \\ Universidade de Vigo \\ xoanp@uvigo.es \\ framallo@uvigo.es
}

Editor das recensións' / Reviews editor

Manuel Fernández Ferreiro (Universidade da Coruña)

1xnanu@udc.es

Comité de redacción / Editorial committee:

Virginia Acuña Ferreira, Univ. de Vigo

Sonia Álvarez López, Univ. de Vigo

Ana Ameal Guerra, Univ. Albany, USA

Mario Cal Varela, Univ. Santiago de C.

Hảkan Casares Berg, Univ. de Vigo

X. Henrique Costas González, Univ. de Vigo

Montserrat Davila Ventura, Univ. de Vigo

Luzia Dominguez Soco, Univ. da Conữa

Manuel Femández Ferreiro, Univ. da Conuña

Eloi Gestido de la Torre, Univ de Vigo
Renée Hayes, Univ. Delawere, USA

Mário J. Herrero Valeiro, Univ da Coruña

Gabriela Prego Vázquez, Univ. Santiago de C.

Esperanza Rama Martinez, Univ. de Vigo

Monserrat Recalde Fernández, Univ. Santiago de $C$.

Gabriel Rei-Doval, Univ. Oxford, U.K.

Miguel Valverde Juncal, Univ. de Vigo

Eduardo Varela Bravo, Univ. de Vigo

Nancy Vázquez Veiga, Univ. da Coruña

Luz Zas, Univ. Santiago de Compastela

Enderezo para o envio de colaboracións / Address to send contributions:

Estudios de Sociolingüistica

Facultade de Filoloxía e Traducción

Universidade de Vigo

Campus das Lagoas-Marcosende, $\mathbf{s} / \mathbf{n}$

E-36200 - Vigo (Galicia), SPAIN

Páxina web / Web page: http:/webs.uvigo.es/ssl/eds

Enderezo electrónico / E-mail: eds@uvigo.es

ISSN 1576-7418. Depósito legal: VG: 603-2000

Tódolos dereitos reservados / All rights reserved

Copyright @ 2002 e 2003 Servicio de Publicacións da Universidade de Vigo 